\title{
Effect of Soil Amendments on White Blister Development of Aamaranthus bicolor Incited by Albugo bliti
}

\author{
Bhimeshwari Sahu, N. Lakpale and Ashish Pradhan* \\ Department of Plant Pathology, College of Agriculture, Indira Gandhi Krishi \\ Vishwavidyalaya, Raipur (C.G.), India \\ *Corresponding author
}

\begin{abstract}
A B S T R A C T
Keywords

Amaranthus, Albugo bliti, Soil amendments

Article Info

Accepted:

14 December 2017

Available Online:

10 January 2018

The field experiments was conducted in the Plant Pathology field, Indira Gandhi Krishi Vishwavidyalaya, Raipur Chhattisgarh in the year 2014-2015 to study the effect of soil amendments on white blister (Albugo bliti) development of Amaranthus bicolor. In all, 11 different organic amendments i.e., dried green leaves of Lantana (Lantana camara), Ipomoea (Ipomoea purpurea), Karanj (Pongamia pinnata), Xanthium (Xanthium strumarium), Oil cakes like Mustard cake, Neem cake, Karanj cake and manures like Vermicompost, FYM, Vermicompost + Trichoderma, FYM + Trichoderma were incorporated in soil 15 days prior to sowing. Disease severity was recorded twice on 20 randomly selected plants - first 15 days after sowing and second before harvest (30 days after sowing). All the experiments were repeated thrice on same plots in same season. Disease severity in three dates of sowing was ranging from 8.05 to $12.80 \%$ and first date significantly lower than that of second and third date of sowing. Overall, it seems that either Neem cake or FYM or FYM + Trichoderma may be amended in soil as per availability to reduce the white blister diseases severity in Amaranthus bicolor.
\end{abstract}

\section{Introduction}

Amaranthus bicolor is an important leafy vegetable (locally known as Lal bhaji) belongs to family Amaranthaceae, in India Amaranthus bicolor is widely cultivated during summer and rainy season in Himachal Pradesh, Uttar Pradesh, Punjab, Gujrat, Maharashtra, Chhattisgarh and several other parts of the country. The leaves and tender stems of Amaranthus are rich in protein, minerals, vitamin A and C. The composition of Amaranthus tender leaf and grains (per 100 $\mathrm{g}$ of edible portion) moisture (\%) 85.70, 9.3, protein $(\mathrm{g})$ 4.0, 15.3, fat $(\mathrm{g})$ 0.50, 7.1, carbohydrates (g) 6.30, 63.10, calcium (mg) 397.0, 490.00, iron (mg) 25.5, 22.40, phosphorus (mg) 83.0, 455.00, vitamin A (IU) 9200, vitamin C (mg) 99, respectively (Aykroyd, 1963). The Amaranthus is liked by one and all and like other crop plants its cultivation is also threatened by biotic and abiotic factors (Yadev et al., 2014). Among the biotic factors, diseases like stem canker (Pythium aphanidermatum), charcoal rot (Macrophomina phaseolina), damping off (Pythium aphanidermatum, Rhizoctinia solani and Aphanomyces sp.), mosaic (Amaranthus 
mosaic virus), Leaf spot (Alternaria tenuissima) and White blister (Albugo bliti) reported on the Amaranthus. White blister disease caused by Albugo bliti is major one, uniformly infects all the area wherever Amaranthus is grown, and reduces the size of the foliage and plants as well. Due to this disease less return received by the farmers as the appearance of affected plants does not look good.

The pathogen Albugo bliti is survives in the form of the oospores formed in plant debris that admixed in soil and serves as primary inoculum for white blister infection for ensuing crop season. The disease appears on the foliage which is to be used directly for vegetable purpose, application of fungicides not at all advisable on any of the leafy vegetables, and farmers are not applying any sort of chemicals for plant protection. In the farmers' routine cultivation practice of growing Amaranthus for vegetable purpose, incidence of white blister disease has to be minimized by non- chemical approach which will be feasible and cost effective. Looking to above facts, the present investigation is carried out to minimize the initial inoculum present in the soil i.e. oospores with the application of soil amendments and thereby reduce the white blister (Albugo bliti) development of Amaranthus bicolor.

\section{Materials and Methods}

The field experiments were conducted in the Plant Pathology field during the year 20142015 in Indira Gandhi Krishi Vishwavidyalaya, Raipur, Chhattisgarh. Soil amendments including dried green leaves, oil cakes and manures were incorporated in the experimental plots two weeks prior to sowing. The powder of dried green leaves of Lantana (Lantana camara), Ipomoea (Ipomoea purpurea), Karanj (Pongamia pinnata), Xanthium (Xanthium strumarium) incorporated into soil @ $1 \mathrm{Kg} / 1.5 \times 1 \mathrm{~m}^{2}$ plot. Oil cakes namely Mustard cake (1333 kg /ha), Neem cake $(750 \mathrm{Kg} / \mathrm{ha})$, Karanj cake (750 $\mathrm{Kg} / \mathrm{ha}$ ) and manures like Vermicompost (25 q/ha), FYM (200-300 q/ha), Vermicompost + Trichoderma $(100 \mathrm{Kg} / \mathrm{ha}), \mathrm{FYM}+$ Trichoderma $(100 \mathrm{Kg} / \mathrm{ha})$ were incorporated in the soil. Vermicompost $(100 \mathrm{Kg})+$ Trichoderma formulation $(1 \mathrm{Kg})$ and FYM $(100 \mathrm{Kg})+$ Trichoderma formulation $(1 \mathrm{Kg})$ mixed well, made heap, covered with moistened gunny bags and kept for 15 days for Trichoderma to multiply. An unamended plot serves as control. Three replication were maintained for each treatment. Disease severity was recorded twice on 20 randomly selected plants first 15 days after sowing and second before harvest (30 days after sowing). Sowing of seeds was repeated thrice on same plots in same season.

Soil sample were collected from upper layer of the different soil amendment treated plots where maximum population of microorganism was concentrated. For assessing microbial population, $1 \mathrm{~g}$ of soil was dissolved in $10 \mathrm{ml}$ of sterile distilled water to make soil suspension and this soil suspension undergo serial dilution so on up to $10^{9}$ dilution. Soil suspension @ $0.5 \mathrm{ml}$ of $10^{9}$ dilution was spread over the solidified potato dextrose agar. After incubation for 3 day at $25^{\circ} \mathrm{C}$ in BOD incubator, colonies of various mycoflora were recorded.

\section{Results and Discussion}

In all, 11 different organic amendments were incorporated in soil and data on white blister disease severity were presented in table 1 . Disease severity in three dates of sowing was ranging from 8.05 to $12.80 \%$ and first date significantly lower than that of second and third date of sowing. In first date of sowing, all the organic amendments reduce disease severity significantly to that of control. 
Among the treatments, lowest disease severity was recorded in Vermicompost (2.07\%) followed by Neem cake $(3.14 \%)$ and FYM $(4.55 \%)$ and they were at par with each other. In second date of sowing, except Lantana, Ipomoea and Xanthium leaf, all other amendments reduce disease severity significantly as compare to that of control. Among the treatments, lowest disease severity was recorded in FYM (5.57\%) followed by Neem cake $(7.09 \%)$ and FYM + Trichoderma (7.38\%) and they were at par with each other. In third date of sowing, except Ipomoea and Xanthium leaf, all other amendments reduce disease severity significantly to that of control. Among the treatments, lowest disease severity was recorded in Karanj leaf (4.06\%) followed by Mustard cake (5.91\%) and FYM + Trichoderma $(6.70 \%)$ and they were at par with each other. Overall, it seems that either Neem cake or FYM or FYM + Trichoderma may be amended as per availability to reduce the white blister severity in Amaranthus. The finding of this study are in close proximity with the findings of various workers on the effect of soil amendments on various soil borne pathogens including Oomycetous fungi (Sun and Huang, 1985; Jeyarajan et al., 1987; Nam et al., 1988; Sun, 1989; Weltzien, 1990; Narendrappa et al., 1992; Szczech et al., 1993; Rajan and Sharma, 2000 and Muryati et al., 2009). Similar kind of result in lentil wilt has been observed by Kumar et al., 2013 which showed that seed treatment with Trichoderma harizanum + Pseudomonas fluorescence gave significant reduction in disease incidence and maximum grain yield an among organic amendments cow dung manure, FYM, spent compost and vermicompost, minimum disease incidence $3.25 \%$ in case of FYM treated plots followed by vermicompost $(4.25 \%)$ and cow dung manure $(4.75 \%)$.

Table.1 Comparative efficacy of various soil amendments on white blister development

\begin{tabular}{|c|c|c|c|c|c|}
\hline \multirow[t]{2}{*}{ S. No. } & \multirow[t]{2}{*}{ Treatment } & \multicolumn{4}{|c|}{ Disease severity (\%) } \\
\hline & & $\begin{array}{c}\mathbf{1}^{\text {st }} \text { date of } \\
\text { sowing }\end{array}$ & $\begin{array}{c}2^{\text {nd }} \text { date of } \\
\text { sowing }\end{array}$ & $\begin{array}{c}3^{\text {rd }} \text { date of } \\
\text { sowing }\end{array}$ & Mean \\
\hline 1 & Karanj leaf & $8.47(3.07)^{*}$ & $11.317(3.5)$ & $4.06(2.23)$ & 7.94(2.94) \\
\hline 2 & Lantana leaf & $8.01(2.98)$ & $17.10(4.24)$ & $7.43(2.88)$ & $10.84(3.38)$ \\
\hline 3 & Ipomoea leaf & $8.543(3.08)$ & $19.25(4.49)$ & $23.63(4.94)$ & $17.14(4.18)$ \\
\hline 4 & Xanthium leaf & $8.723(3.11)$ & $16.84(4.21)$ & $24.89(5.05)$ & $16.81(4.00)$ \\
\hline 5 & Neem cake & $3.143(1.92)$ & $7.09(2.83)$ & $8.98(3.11)$ & $6.40(2.63)$ \\
\hline 6 & Karanj cake & $8.917(3.11)$ & $14.60(3.93)$ & $8.95(3.10)$ & $10.82(3.39)$ \\
\hline 7 & Mustard cake & $10.69(3.34)$ & $14.28(3.90)$ & $5.91(2.62)$ & $10.29(3.29)$ \\
\hline 8 & Vermicompost & $2.073(1.56)$ & $8.08(3.01)$ & $8.39(3.04)$ & $6.18(2.54)$ \\
\hline 9 & FYM & $4.557(2.13)$ & $5.57(2.55)$ & $9.35(3.20)$ & $6.49(2.64)$ \\
\hline 10 & Vermicompost + Trichoderma & $5.103(2.23)$ & $8.61(3.09)$ & $11.92(3.59)$ & $8.54(2.94)$ \\
\hline 11 & FYM + Trichoderma & $7.473(2.62)$ & $7.38(2.88)$ & $6.70(2.74)$ & $7.18(2.76)$ \\
\hline 12 & Control & $20.58(4.59)$ & $23.6(4.95)$ & $26.86(5.27)$ & 23.68(4.89) \\
\hline & Mean & $8.05(2.79)$ & $12.80(3.64)$ & $12.25(3.48)$ & \\
\hline
\end{tabular}

\begin{tabular}{|l|c|c|}
\hline \multicolumn{1}{|c|}{ Factors } & SE(m) \pm & CD $(\mathbf{P}=\mathbf{0 . 0 5})$ \\
\hline Factor $(\mathbf{D})$ & 0.098 & 0.277 \\
\hline Factor $(\mathbf{T})$ & 0.196 & 0.554 \\
\hline Factor $(\mathbf{D}$ X T) & 0.339 & 0.959 \\
\hline
\end{tabular}

*Data in parenthesis are square root transformed value 
Table.2 Effect of soil amendments on soil borne mycoflora

\begin{tabular}{|c|c|c|c|c|c|c|c|c|c|c|}
\hline \multirow[t]{2}{*}{ S. No. } & \multirow[t]{2}{*}{ Treatment } & \multicolumn{9}{|c|}{ No. of Colony of different mycoflora $\left(\times 10^{9}\right)$} \\
\hline & & Rhizopus & Fusarium & $\begin{array}{l}\text { Aspergillus } \\
\text { flavus }\end{array}$ & $\begin{array}{l}\text { Aspergillus } \\
\text { niger }\end{array}$ & $\begin{array}{l}\text { Aspergillus } \\
\text { fumigatus }\end{array}$ & Penicillium & Sclerotium & Bipolaris & Total \\
\hline 1 & Karanj leaf & - & 18 & 28 & 1 & - & 39 & - & 1 & 87 \\
\hline 2 & Lantana leaf & - & 3 & 26 & 8 & - & 47 & - & - & 84 \\
\hline 3 & Ipomoea leaf & 1 & 28 & 4 & 1 & 45 & - & - & - & 79 \\
\hline 4 & Xanthium leaf & - & 16 & 13 & 3 & 3 & 1 & - & - & 36 \\
\hline 5 & Neem cake & - & 1 & 2 & 21 & - & 11 & - & - & 35 \\
\hline 6 & Karanj cake & - & 4 & 5 & - & - & - & - & - & 9 \\
\hline 7 & Mustard cake & - & - & 9 & 1 & - & 38 & 1 & 2 & 51 \\
\hline 8 & Vermicompost & - & 15 & 4 & - & - & 1 & - & 1 & 21 \\
\hline 9 & FYM & - & 5 & 26 & 1 & - & 64 & - & 1 & 97 \\
\hline 10 & $\begin{array}{l}\text { Vermicompost } \\
\text { +Trichoderma }\end{array}$ & - & 2 & 4 & 1 & - & 18 & - & - & 25 \\
\hline 11 & $\begin{array}{l}\text { FYM+ } \\
\text { Trichoderma }\end{array}$ & 1 & 3 & 12 & - & - & 36 & - & 1 & 53 \\
\hline 12 & Control & 1 & 8 & 6 & 2 & 2 & 24 & - & 2 & 45 \\
\hline
\end{tabular}

The significance of adding soil amendments in soil and its effect on soil borne plant pathogens had been attributed by Bonilla et al., (2012). According to him, organic matter inputs affect the soil physic-chemical properties and soil micro biota, influencing different parameters such as microbial biomass and diversity, community structure and microbial activities or functions. The enhancement of soil suppressiveness using organic amendments has been widely described specially for soil borne disease.

In the present investigation, majority of soil amendments increases the soil born mycobial population (Table 2) which may directly or indirectly affect the activities of soil borne inoculum of A. bliti. Amendment of soil with decomposable organic matter in recognized as an effective method of changing soil and rhizosphere environment. Such changes adversely affect the pathogens and improver plants to resist infection through better vigour and/or altered root physiology (Etebarian 2006). Decomposition also increases microbial activity both quantitatively and qualitatively. Thus, the amendments can reduce inoculums density, inoculums capacity, host proveness and also increase host resistance; the net result having reduction in disease severity.

\section{Acknowledgements}

This manuscript is the part of M.Sc. (Ag) thesis work. Hence, the first author would like to thank the Department of Plant Pathology, College of Agriculture, Indira Gandhi Krishi Vishwavidyalaya, Raipur, Chhattisgarh for the technical support.

\section{References}

Aykroyd, W.R. 1963. ICMR Special Rept. Series No. 42.

Bonilla, N., Gutierrez- Barranquero, J.A., Vicente, A.de. and Cazorla, F. M. 2012. Enhancing soil quality and plant health through suppressive organic amendments. Diversity. 4(4): 475-491.

Etebarian, H. R. 2006. Evaluation of Trichoderma isolates for Biological Control charcoal coal stem rot in Melon caused by Macrophomia phaseolina. J. Agric Sci Technol. 8: 243250.

Jeyarajan, R., Sabith, Doraiswamy, Bhaskaran, R. and Jayaraj, S. 1987. Effect of Neem [Azadirachta indica] and other plant products in the management of plant diseases in India. Natural pesticides from the Neem tree Azadirachta indica A Juss and other tropical plants. 635-644. 
Kumar, V., Garkoti, A. and Tripathi, H. S. 2013. Management of vascular wilt of lentil through bio control agents and organic amendments in tarai area of Uttarakhand state. The Bioscan. 8: 575577

Muryati, L.O., Emilda, D., Santoso, P.J. and Sunarwati, D. 2009. Effect of organic fertilizers on susceptibility of potted durian seedlings to Phytophthora diseases. J. Fruit and Ornamental Pl. Res. 17: 67-77.

Nam, G., Jee, H.J. and Kim, C.H. 1988. Studies on biological control of Phytophthora blight of red pepper. II. Enhancement of antagonistic activity by soil amendment with organic materials. Korean J. Pl. Protec. 4: 313-318.

Narendrappa, T., Gowda, D.N. and Narayanaswamy, H. 1992. Integrated management of soil borne diseases of tobacco in nursery. Farming Syst. 8: 4143.

Rajan, P.P. and Sarma, Y.R. 2000. Effect of organic soil amendments and chemical fertilizers on foot rot pathogen (Phytophthora capsici) of black pepper (Piper nigrum L.). Spices and aromatic plants challenges and opportunities in the new century Contributory papers
Centennial conference on spices and aromatic plants, Calicut, Kerala, India. 249-253.

Sun, S.K. 1989. Use of soil amendment for the control of soilborne diseases. Organic farming Proceedings of a symposium held at Taichung District Agricultural Improvement Station.1: 141-155.

Sun, S.K. and Huang, J.W. 1985. Formulated soil amendment for controlling Fusarium wilt and other soilborne diseases. Pl. Dis. 69: 917-920.

Szczech, M., Rondomanski, W., Brzeski, M.W., Smolinska, U. and Kotowski, J.F. 1993. Suppressive effect of a commercial earthworm compost on some root infecting pathogens of cabbage and tomato. Biol. Agric. and Horticl. 10: 47-52.

Weltzien, H.C. 1990. The use of composted materials for leaf disease suppression in field crops. Monograph British Crop Protection Council. 45: 115-120.

Yadav, R., Rana, J. C., and Ranjan, J. K. 2014. Analysis of variability parameters for morphological and agronomic traits in grain amaranth (Amaranthus sp) genotypes. The Bioscan. 9: 1661-1665

\section{How to cite this article:}

Bhimeshwari Sahu, N. Lakpale and Ashish Pradhan. 2018. Effect of Soil Amendments on White Blister Development of Aamaranthus bicolor Incited by Albugo bliti. Int.J.Curr.Microbiol.App.Sci. 7(01): 2072-2076. doi: https://doi.org/10.20546/ijcmas.2018.701.249 